\title{
Pedagogic Being in a Neoliberal School Market: Developing Pedagogical Tact Through Lived Experience
}

\author{
Ilona Rinne, University of Gothenburg, Sweden \\ E-mail: ilona.rinne@gu.se
}

\begin{abstract}
Exploring teaching as an upper secondary school teacher through lived experience offers pedagogical insights that have been challenged over a period of 25 years, when neoliberal educational policies gradually transformed the conditions for teaching in Swedish schools. The article is grounded in the assumption that the teaching profession is complex and there are multiple tacit dimensions inherent in being and becoming a teacher. Several of these dimensions are captured by the notion of pedagogical tact and have to be learned through practice. However, over the past few decades, the implementation of neoliberal policies in the Swedish education sector have changed the conditions for teaching, and created an area of tension between the teacher's pedagogical alignment and the educational practices influenced by neoliberal values. The aim of the study is to describe how the author experienced these tensions, and what they meant for her becoming and being a teacher in three different pedagogical sites: a higher education preparatory program, a vocational preparatory program, and in adult education. The description is grounded in the lifeworld phenomenological approach and carried out through personal narrative.
\end{abstract}

Keywords: pedagogical tact, neoliberal educational policies, lived experience

\section{Introduction}

Every pedagogic practice has its own specific traits and peculiarities to which teachers must adjust. The following description is grounded in my own lived experience of becoming and being an upper-secondary school teacher in three different pedagogical practices over a period of 25 years. Being a teacher in these sites, I experienced divergences in the requirements of each situation, which made me develop my pedagogical understanding of every student's uniqueness and special needs. Such a pedagogical understanding is embraced by the notion of pedagogical tact, which is described by van Manen (2015) as "a feeling-understanding" ( $p$. 78) that includes the teacher's sensibility and sensitivity to every child's uniqueness.

I started my teaching career at a higher education preparatory program in 1989 when the Swedish education system had just started facing changes resulting from neoliberal policies such as educational marketization, effectiveness and measurement. These changes 
were not yet influencing everyday teaching in the upper secondary school where I worked. I had a considerable amount of professional autonomy in developing my teaching skills and in establishing pedagogical relationships with my students. After 15 years at this school, I confidently developed my pedagogical skills. However, I changed workplace and ended up at a vocational preparatory program in an upper-secondary school that was completely different from the one I was used to. Changing the workplace not only revealed a lack of contextsituated pedagogical experience, which made me feel like a novice teacher again, but I also faced the profound impact that neoliberal policies were starting to have on teachers' work lives in Sweden. More attention was paid to economic issues than to pedagogical purposes. Students were treated as customers - the ones who bring money to the school - and not as human beings needing to be understood in their own uniqueness. This increased educational marketization became a disruption in my attentiveness to pedagogical needs.

The neoliberal assault on the pedagogical core of teaching became even more tangible when I changed my workplace for the second time. Once again, I faced a teaching practice that was completely different from the previous one. In this new teaching assignment, I was supposed to prepare adult learners for the needs of the labor market, but powerful economical interests were pressuring me to let the students pass my courses as quickly as possible in order not to burden the school with costs by keeping them longer than necessary. I experienced more strongly than before that my pedagogical acting was constrained by the consequences of the emerging school market in Sweden. The implementation of pervasive neoliberal educational policies gradually transformed the conditions for teaching. These changes challenged my ability to develop pedagogical tact in student encounters and created tensions between my pedagogical alignment and the educational practices influenced by neoliberal values. The aim of this discussion is to describe how I have experienced these tensions, due to neoliberalism, and what this meant for my being a teacher. I will highlight some challenging moments of my teaching from three different pedagogical sites $^{1}$ : a higher education preparatory program, a vocational preparatory program, and an adult education program. The following lived descriptions are grounded in the lifeworld phenomenological approach (van Manen, 2007, 2015; Roth, 2002) and derive from my memory, which means that the study is empirically based on autobiographical memory described through first-person epistemology (de Anda \& Geist-Martin, 2017; Klein \& German, 2004; Levine \& Pizarro, 2004).

\section{The Neoliberal Eclipse of Teaching}

I have experienced how the implementation of pervasive neoliberal educational policies, that started in the early 1990s, gradually influenced and transformed the conditions for teaching in Sweden resulting in several reforms. Free school choice and a nationwide voucher system were brought in, allowing private (so-called "independent") schools to be run with public funding. ${ }^{2}$ In countries where the voucher system is used it exists for tuition at private schools. In Sweden, there are no fee-paying schools (except for boarding schools) and this makes the voucher system an unusual feature of the Swedish school system compared with other countries (Erixon Arreman \& Holm, 2011). The implementation of the neoliberal

\footnotetext{
${ }^{1}$ In Sweden, upper secondary school is divided into two programs, one that prepares students for higher education (higher education preparatory program) and one that is directed towards a particular occupation (vocational preparatory program).

${ }^{2}$ Today, private schools enroll approximately one-fourth of all Swedish upper secondary school students.
} 
educational policies meant that more attention was paid to economic issues, measurement and achievement of educational effectiveness through technocratic models, preferably grounded in evidence-based research (Erixon Arreman \& Holm, 2011; Carlgren, 2009). The push for evidence-based education in Sweden prompted the establishment of the Swedish Institute for Educational Research with the mission to synthesize the findings of educational research, and to make research outcomes more accessible to public school teachers (Levinsson, 2017). However, the authorities' desire for an evidence-based approach and for clear guidance in pedagogical practice in order to find "what works" (Biesta, 2007; Evaldsson \& Nilholm, 2009) has overshadowed the complexity of teaching, favoring teaching practices that are managerial, technocratic, and assessment-driven.

The call for an evidence-based approach seeks to shed more light on measurement of preset standards (Biesta, 2017). Less attention is therefore paid to the understanding of professional actions as interaction between human beings who "never appear just as objects of intervention but always also as subjects in their own right" (Biesta, 2017 , p. 323). Thus, the central point of departure in this article is that a student can never be reduced to an object, but must be seen in his/hers own uniqueness: "a teacher must observe a child pedagogically" which means to "keep in view the total existence of the developing child" (van Manen, 2015, p. 63). Consequently, the core of teaching captured by the notion of pedagogical tact is existing regardless of prevalent practice governed by specific policies. Nevertheless, Swedish teachers are pressured to adapt to the current neoliberal reforms, conforming to new standards in teaching. This creates a tension between the teachers' pedagogical practices and government influence that threatens the teachers' practice forcing them to become knowledge managers through government endorsed neoliberal educational policies.

\section{Pedagogical Tact}

The concept of pedagogical tact is based on the idea of a transactional and dialogical educational process introduced by Plato and further elaborated by Friedrich Herbart in his didactic theories as presented in Allgemeine Pädogigik in 1808. Herbart's description of pedagogical tact derives from the question of "the way a good educational practice is dependent on scientific educational theory" (Kenklies, 2012, p. 269). Clearly, this addresses the connection between theory and practice using the notion of pedagogical tact, which allows the application of theory to practice with respect to the individuality of every single case (Kenklies, 2012). Therefore, only through practice it is possible to learn how to adapt to new situations. According to Herbart, teaching is not rooted in "I-monism" of the teacher or the student (Kenklies, 2012). The student is thus not an object but a partner (Ich-Du Beziehung). The actual substance and meaning of the relationship between the teacher and the student is grounded in the teacher's permanent readiness to help (Angebot zur Hilfe) (Fišer, 1972).

The word tact has its origin in the Latin verb tangere, to touch metaphorically yet specifically concerning the capacity to "touch" a person "by word, by look, by gesture" (Fišer, 1972, p. 467). Furthermore, it can mean to strengthen, to encourage, to express concern and trust, but also to make demands, to give disapproval, to judge, but always to be ready to help (ibid.). The concept of pedagogical tact has been further elaborated by Jakob Muth (Friesen \& Osguthorpe, 2018) and van Manen $(1991,2015)$ in a pedagogical context within phenomenological research. Van Manen (2015) distinguishes four ways of pedagogic being: sensitivity, sense, sensibility, and acting. Pedagogical sensitivity includes the teacher's ability to understand the inner life of the child. Pedagogical sense is about the interpretation of different features of the inner life of the child. Pedagogical sensibility concerns the teacher's judgment for "how far to enter into a situation and what distance to keep in individual circumstances" (van Manen, 2015, p. 98). And finally, pedagogical acting means the teacher's 
ability to distinguish what is good and what is not good for the child. Pedagogical tact is incorporated into pedagogical wisdom and understanding, as an embodied knowledge, and cannot be learned as a method or a technique (van Manen, 1991, 2015). Through practice, teachers learn to adapt to new situations, and it is not always possible to decide in advance what will be required. Pedagogical awareness is a consequence of a teacher's sense of tact. Van Manen (1991) emphasizes that one fundamental task of teaching is pedagogical, which again is realized in practice through tact.

\section{Understanding Lived Experience}

The methodological point of departure in this study is that teaching cannot be studied as a remote measurable activity, but must be considered as an experienced, livedthrough, practice. Van Manen (2007) claims "a phenomenology that is sensitive to the lifeworld explores how our everyday involvements with our world are enriched by knowing as in-being" (p. 13). In order to capture important, tacit dimensions of being a teacher, and to understand further the nature of being, I ask what is the distinguishing feature of the existence for a teachers' practice. Living, people relate interpretively to their lives, they understand themselves in a continuous process of self-interpretation, experience and reinterpretation. Understanding is thus brought about by time, which means that the past and the future acquire meaning through the present. According to Heidegger (see Gibbs, 2014), understanding is shown through action within the context of the taken-for-granted concept. When the-taken-for granted is disturbed, we are "awakened" and we "reorient and reassess our relationship to the newly disclosed circumstances" (p. 148). Roth (2002) points out that teaching is carried out in a domain that is taken for granted as long as everything flows as usual in the classroom. As teachers, we begin to reflect about different situations in the classroom when something breaks the flow, or in Roth's words - when the known becomes unknown. Roth describes such situations as breakdown. Thus, we understand the lived-in concept in a new way: as experienced on my first day at my new vocational upper secondary school.

\section{Reflecting on Lived Experience Through Memory}

One crucial question in this study is how lived experience can be researched and described. According to van Manen $(1997 ; 2014)$, lived experience has a temporal structure and "can never be grasped in its immediate manifestation but only reflectively as past presence" (van Manen, 1997, p. 36). How we act in a situation by reflecting on it allows for memory understanding. Thus, the task of phenomenological research and writing is "to construct a possible interpretation of the nature of a certain human experience" (van Manen, 1997). Lived experience derived from my memory forms the phenomenological recounting of teaching that was disrupted. This raises a question about how lived experience can be recalled and reflected on based on autobiographical memory and described through first-person epistemology (de Anda \& Geist-Martin, 2017; Klein \& German, 2004; Levine \& Pizarro, 2004). Therefore, important questions to consider are what I remember and why, and whether, I can rely on my memory, and what can be drawn from the connection between memory and self. Klein and German (2004) claim that self "is to be defined in terms of memory" since it is "constructed from the recollection of personal experience" (p. 461). Autobiographical memory can thus be characterized as a first-person epistemology, which enables us to examine the question of "how we come to know who and what we are" (Klein \& German, 2004 , p. 461). In a sense, we are our memories or at least memories are fundamental in selfunderstanding because what we have done has led us to who we are.

Looking back at my years as an upper secondary school teacher, I realize that there are some situations that I remember better than others. Such situations are primarily 
connected with special landmarks (de Anda \& Geist-Martin, 2017), such as doing something for the first time or situations that evoke strong feelings. Levine and Pizarro (2004) show that memory is influenced by emotions. They note that emotional events are remembered better and that the memories of them tend to be more long-lasting than non-emotional ones. Thus, emotions serve as a powerful organizing force.

In the following description, I will draw attention to challenging situations in my teaching practice that I remember as highly emotional, and that were somehow prompted by the increased neoliberal reach into Swedish upper secondary school. This lived experience description will be structured in three themes over three different educational practices. Critical to this discussion is how neoliberalism challenged my development of pedagogical tact in these practices. I will describe the forming of my teacher identity while working in a higher education preparatory program during the years when the neoliberal educational policies were not yet so obvious. I elaborate how my pedagogical tact was developed by the challenges I faced when moving to the vocational preparatory program, and how I was exposed by the increasing dominance of instrumentalization, marketization, and efficiency. Finally, I will describe how such destructive neoliberal practices and values suspended my readiness to help students in adult education.

\section{Higher Education Preparatory Program: An Evolving Identity}

When I started my teaching career at the one of the oldest upper secondary schools in our town, as a Swedish teacher in a higher education preparatory program, neoliberal policies were not entrenched. The school was built at the end of the $19^{\text {th }}$ century with heavy doors and huge windows. Looking at the big building from the parking lot out front, I always got a feeling of a monster leaning over me. Twenty-five years later I entered this school as a teacher educator in order to visit one of my student teachers. As I opened the heavy door the strong emotions that I had as a novice teacher hit me immediately: a constant feeling of insufficiency and insecurity, maybe because I was the youngest and most inexperienced among my colleagues. Most of them were at least 20 years older than me, while the students were just a few years younger. I remember I was concerned about the closeness in age between me and my students and I recall worrying about how I could manage establishing a position of authority.

The student teacher whom I came to visit opened one of the heavy doors in the corridor and we entered the classroom. The first thing I laid my eyes on was the rostrum on which the teacher's desk was placed. It was part of the original structure of the building and was supposed to give the teacher power and authority which I, however, never felt when standing there. On the contrary, seeing all the faces full of expectation in front of me gave me a feeling of insecurity and made me shiver from fear inside. In every lesson, I was supposed to be the person in authority who knows what to say and what to do. I was supposed to give my students new knowledge while making my teaching interesting. Inexperience spoke to me in mental whispers: how could I teach these young people anything? Unfortunately, there was no tradition of teacher cooperation as part of a mentoring process at my first school. Although all my colleagues were very friendly, and answered all my questions patiently, I realized that no one could teach me how to do my job. I had to figure it out on my own.

After years of effort, reflecting, enduring, and searching for my teacher identity, I became a more secure teacher. I had a considerable scope of action concerning the methods of teaching and the interpretation of the subject content. I felt free to discover the most suitable and efficient ways to work together with my students. The students were highly motivated and most of them were interested in the subjects I was teaching. I felt that I was trusted and that I had a lot of freedom in developing my teaching skills and pedagogical relationships. 
Looking back, I realize that in becoming a more experienced teacher, I had developed pedagogical tact even if I was not fully aware of it at that time.

The neoliberal educational policies had not yet permeated my pedagogical practice in any other senses than economic circumstances unfolding in Sweden. Measurement and effectiveness were not yet focused on in any broader sense, but since the voucher system ${ }^{3}$ was introduced, the financial issues of the school became unavoidable and they were often raised and discussed by the school principal. The voucher system implied that the funding of the school was based on the number of students, which entailed that students could be considered as customers in a school market. However, the strong traditions of the school and high demands on students' learning delayed the development of neoliberal marketing thinking in this school. Therefore, these policies were not so obvious and did not affect my work to any great extent. The voucher system was questioned by the teachers at the school, and many of us hoped that this was a passing phenomenon.

\section{Vocational Program: Keep the Students at All Costs}

All my knowledge in the subject content that I had spent so much time developing while working at the higher education preparatory program was suddenly nearly useless when I had to change workplaces and started in the vocational preparatory program. Content knowledge was simply not important at my new workplace. The students showed clearly in their body-language they just did not care for Swedish as a subject, not for my teaching methods and even less for me personally. The students at my new school were noisy and rude and behaved in a way that I had never experienced before, and a few refused to work at all. I found it painful to see how the assignments I had put an effort into creating, trying to make a lesson interesting, were immediately crumpled up and thrown away in the rubbish basket or folded into paper airplanes flying all around the classroom. Seeing my assignments transformed into discarded materials felt as though a part of me was being rejected, denied, and thrown away by my students.

From a curricular ${ }^{4}$ stance, the same syllabus was followed in all the upper secondary school programmes and this qualified all students for higher education. There was an attempt to move away from the profound division of upper secondary school students into "theoretically oriented" suitable for higher education and "practically oriented", suitable for manual labour occupations. My experience at the vocational program shows that it was not possible to follow the same syllabus in different programs mainly because the vocational program was the last hope for education for many students who, for different reasons, had failed in Swedish primary school. The classes were very heterogeneous, containing a mix of highly motivated students with a great interest in education in general and students who had a specific interest in the vocational focus. There were also those who did not really fit anywhere programmatically. Since the school budget was based on the voucher system the funding depended on how many students applied to attend our school. During my years at the

\footnotetext{
${ }^{3}$ The voucher system is described in the beginning of this article.

${ }^{4}$ In the upper secondary school in Sweden, a new curriculum was implemented in 1994, before which the higher education preparatory programmes were three-year programmes and the vocational ones were two-year programmes. One significant change in the curriculum was that all upper secondary school programmes became three-year programmes and were aimed at preparing students for higher education. This idea was criticised by the right-wing government, which came to power in 2007, and due to changes in the 2011 curriculum, courses in the theoretical subjects are now shorter in vocational programmes than in higher education preparatory programmes.
} 
vocational preparatory program, it became more obvious how important it was to attract students in every possible way and ensure retention. In contrast to my previous school, I was now often told by the principal to do everything I could in order to prevent students from dropping out. Every student who did not finish their studies, or did not manage to complete assignments on time, resulted in extra costs for the school because it required more teaching.

A consequence of enforced student retention was lowered academic standards and a narrowed curriculum in subjects as Swedish, English, and mathematics, since these were not priority subjects for students destined for vocational programs. The unwritten policy of the school was moving in a direction that can be summarized as, "Come on! Make it easy. They are only going to be truck drivers." This mantra was in keeping with neoliberal policy in positioning the educational focus to be limited on skills specific to entrepreneurial subjects in order to make the students employable. Education had a prime purpose: shape students for the needs of the market. Therefore, students did not acquire basic knowledge in languages, mathematics, or critical thinking. Consequently, in response the teacher too became evermore narrow and market-driven, instead of more pedagogically tactful. I felt that the subject I was teaching was limited to elementary basics, and the value of knowledge was demonstrated in being crumpled up and thrown into a rubbish basket. All the while, the school was trying to survive in a competitive school market by keeping the students at all costs. Thus, the focus in the everyday school practice shifted from pedagogical issues to economic ones, which dehumanized students and deprofessionalized teachers.

\section{Seeing Beneath the Surface}

The increasing dominance of neoliberal policies at the vocational program overshadowed pedagogical tact by forcing teachers to abide by instrumentalization, respond to marketization, and be subjected to academic efficiency through measurability, academic accountability reflected in student performance and their final mark. Thus, less attention was paid to every student's needs and personal development. I was frustrated by not being able to respond to my students' needs sufficiently and it made me sad to see so many of them getting lost in a neoliberal practice in which they could not find any meaning at school or see their future purpose for which I was preparing them. Their reaction was to create a hostile atmosphere and constantly put me to the test. One noisy lesson when no one was listening while I was explaining a task, I just gave up. I picked up my things and said calmly, "All right. You don't need me here, so I'll just leave you to yourselves. Do whatever you want. Goodbye!" In a second there was complete silence. They just stared at me:

No! Please, don't go!

We're sorry!

We promise to be quiet!

They begged me to stay. It was not a reaction that I had expected. I was mostly surprised because the minute before they had been behaving as though they did not see me at all. Were they just testing the boundaries while keeping full control over the situation? I must have looked sad because the rest of the lesson everyone hushed as soon as anyone raised his voice. That moment made me see that there was a lot of sympathy among the students towards me. Their rude behavior was only a surface, a way to maintain a certain image. Indeed, beneath that they were vulnerable, insecure and even frightened. Their rudeness was never addressed to me personally. It was more an expression of hopelessness created by bad experiences of school, and I felt that beyond the tough surface, they were reaching for human contact with me or as van Manen (2015) describes it "a close human relation, intimacy, connectedness" (p. 107). My students and I had developed a pedagogical relation and this was the reason that $I$ 
could never really get angry with them. I could finally see who these students really were and what they needed - pedagogical seeing (Saevi \& Foran, 2012).

The more I got to know them, the more I understood that the reason for their poor knowledge in school subjects was not a lack of intellect, but a lack of adequate teaching. Many students were really bright, but they never got a fair chance to develop their skills. Having no supportive environment for studies at home, they were completely dependent on the school in this respect. Because of previous failure in primary school, most of the students did not have the knowledge required at upper secondary school level, which meant that the teaching had to be adjusted to their academic level, otherwise it would be pointless.

If I had stayed at the higher education preparatory program, I would never have had the opportunity to further develop the sense of what is needed in situations different from those I was used to. Starting at the vocational program was a disconcerting "break" for me which put my skills to the test and strained my ability to form pedagogical relationships. I was forced to reconsider teaching and find new ways of doing my job. I ended up in a practice so different from the one that I was used to, and it disrupted my embodied, taken-for-granted experience. Subject knowledge was not primary in the same way as before and I had to develop new skills, such as getting my students' attention while explaining an assignment or responding to disrespectful behavior. A teacher's instant reaction when being confronted by unexpected rudeness can be to question the behavior by reprimand and punishment. However, such a way would not lead to any solution and it is not consistent with pedagogical tact. Being a teacher at the vocational program made me develop a pedagogical sense - an ability to interpret the meaning of my students' behavior. At that time, I could not relate my action to pedagogical tact, since I was not yet aware of it. However, looking back at the development of my pedagogical skills, I understand that developing pedagogical tact was a way to survive as a teacher in a pedagogically demanding practice governed by economic issues.

\section{Adult Education: Readiness to Help}

My third workplace was in a school that provided education for adults at primary and upper secondary school level. The students were mainly foreigners. There was a mix of immigrants, refugees and foreign students, as well as researchers who were staying in Sweden temporarily. The contrast between the vocational program and the adult education program was enormous. Friendly faces smiled at me while greeting me in the morning. Students reached out respectfully for the assignments with both hands and said, "Thank you, teacher!" After five years at the vocational program, I was not used to such politeness. Standing at the whiteboard, explaining some task, I just waited to be interrupted: "Is not anyone going to shout something out loud? Is anyone going to throw something? Why are they so quiet?" I thought. The readiness for constant interruption was an embodied feeling in me. I was constantly ready to act, either by staring at someone or hushing and not needing to do that felt strange. It took me some time to get used to the friendly atmosphere at my new workplace.

I was teaching Swedish, as a second language, to students who lived in all kinds of circumstances. Some came to a pre-arranged life in Sweden through marriage or work; some had escaped war and oppression and had to start all over again in their new country. Finding a job, providing for their family, taking care of children, was very stressful for adult students. On top of that, they had to learn a completely new language. I got to know many life stories, and I learned a lot about their home countries and their journeys that brought them to Sweden. This affected me deeply and I wanted to do everything I could to help my students to learn a new language and to re-settle in their new homeland. 
My readiness to help my students was, however, overshadowed in several aspects. Firstly, in adult education it became obvious that the conditions for teaching had become more and more governed by administrational and financial outcomes; rather than pedagogical ones. The consequences of the competitive school market resulted in increasing pressure and demands for efficiency from the authorities. Even more than before, I had a sense that I could not entirely do a good job due to circumstances that were beyond my control. I felt as I was working at a conveyer belt - a revolving door-moving students along as fast as possible, materially as production. It was learning as a commodity. The composition of the class changed regularly as the students left the school for different reasons and new ones came to fill their places. It was in the school's financial interest to be efficient and to let every student pass the courses as quickly as possible. The school was supposed to prepare these adult learners for the needs of the labor market and the system encouraged students to take jobs below their level of education, in order not to burden the school with costs keeping them longer than necessary. Since the organization was primarily governed from a financial point of view, I experienced more strongly than before that I was a representative of an institution in which I had no ability to influence the conditions established there and that my pedagogical acting was constrained by these conditions. I had therefore sometimes to act in a way that I considered was not in the pedagogical best interest of the students, by letting them to move to the next level too early in their educational process.

\section{The Primacy of Grading}

My readiness to help collided with the formal aspects of my professional work particularly in grading. The grading system in the Swedish schools gives the teacher scope for interpretation, and consequently, the authority to decide each student's grades. As a teacher, I found myself in endless moral dilemmas: Where is the dividing line between passing and not passing? Which shortcomings in a students' language should I ignore in grading? I could not help thinking of the serious consequences that not passing the course could lead to for these students: not getting a job, or not getting the opportunity to continue their studies. For adult learners, who, on top of everything, had to start a new life in a new country, with all the inherent pressures this entailed, this could be more serious and damaging than for young students finishing upper secondary school. Furthermore, if they did not pass the course within the given time, and dropped out of the system, there were no guarantees that they could start their studies again soon. At the same time, all teachers were constantly reminded of the weak financial situation of the school, and the additional costs created by every student who did not pass the courses in time. In this way, student failure became an economic problem for the school (cf. Savage, 2017). This aspect differs strongly from the conditions for teaching that I had experienced at the beginning of my career, when pedagogical, and not financial, issues were primary.

Constant changes in the composition of the classes and the lack of financial stability created a slightly chaotic situation. Despite this, the relational aspects of teaching became even more obvious in adult education than they were at my previous workplaces. For many students, I was one of the few contacts they had with Swedish society. They could turn to me with all sorts of questions. Sometimes they told me personal problems in life, which gave me a deeper understanding of the conditions they were enduring. Their stories touched me, and I wanted to help them as best I could, but I had to watch out and not let sympathy towards my students influence the more formal commitments such as grading. I was constantly concerned by the consequences of grading on a student's future. Giving low grades was not consistent with being supportive and creating an approving atmosphere for learning in the classroom. I wondered how low grades could encourage a desire to learn if the student 
had already done his or her best. Furthermore, from a neoliberal point of view, low grades were not considered as high currency in the educational marketplace-they could give the school a bad reputation. This complexity was especially obvious when I met my students face-to-face in a grade conference and saw their sad and disappointed looks. It made me feel responsible in many ways. Was my teaching good enough? Was I too demanding? Did the teaching methods I used benefit students' learning, or should I try other methods? I was struggling between what I wanted to do for my students, as a human being, and what I was obliged to do as an institutional representative (cf. Westfall-Greiter \& Schwarz, 2012). From a pedagogical perspective, I wanted to act for the sake of my students and, if needed, give them more guidance and time for studying the language before grading. However, in a system governed by neoliberal educational policies focusing on technocratic models, efficiency and economic issues, it was not possible.

\section{Pedagogic Being in a Neoliberal School Market}

My lived experience of becoming a teacher shows how the pedagogical tactful skills that I developed through the years were increasingly challenged by the neoliberal policies implemented in Swedish upper secondary school. In the beginning of my teaching career, I was less controlled and governed by non-pedagogical issues than in the end, when the influences of neoliberalism became stronger. Thus, the consequences of this ideological and political restructuring, such as the insistence on economic productivity and efficient student outcomes described above, impeded my possibility to develop and exercise pedagogical tact. I have experienced teaching that has become more standardized and normative, following technocratic models, putting economic responsibility on teachers' shoulders. Such a development requires a considerable shift in the purpose of teachers' work and potentially obstructs the pedagogical understanding and wisdom captured by the notion of pedagogical tact as the core of teaching (van Manen, 1991, 2015).

The influence of neoliberal policies has generally affected both the teacher and the student in many ways. Not least, school choice meant significant school segregation in Sweden, and the Swedish school system has become one of the most decentralized in the world (Erixon Arreman \& Holm, 2011). The privatization of the schools has led to competition in a quasi-market where every school's budget is based on the voucher each student brings. Therefore, it is in every school's financial interest to attract "non-problematic" students with no special needs that may risk being a burden to the budget. This creates a division of schools into "good" and "bad," and as a result of this division, expectations on students are generally lowered and their opportunities to grow are narrowed (Savage, 2017). I have experienced this clearly while working in both vocational and adult education programs. Neoliberal accountability standards jeopardize educational equality by classifying students from vocational programs as "laborers," with lower demands on their school performances. However, there have always been students with low self-esteem, bad experiences in primary school and a low level of academic aptitude. Teaching these students can be a challenge, but in a time when economic interests dominate the school system, these students are at risk of being left behind. Thus, marketization and school segregation driven by the neoliberal agenda have not been beneficial to students who fail in school (Beach, 2018; Savage, 2017). Nor has it benefitted students who have done well in school. Result-oriented education with a focus on financial issues has resulted in generally lower demands on students and consequently lowered standards of student performance. Accordingly, there has been a significant weakening of both equality and school results.

Teaching practice may look easy but, as described by Labaree (2000), there is "no form of professional practice that is more demanding" (p. 231), not least because teaching 
requires establishing and actively managing an emotional relationship with the students, who are in the classroom under duress. The teaching profession is complex and multiple and must be learned through practice. "We become teachers by being teachers" (Roth, 2002, p. xix). Thus, as revealed by the lived experience offered in this article, there are skills involved in the teaching profession, which cannot be taught theoretically or be grasped by rationalist models of teaching. Teaching must be experienced, lived-through, in every specific pedagogical practice, which has its own features and its own conditions for acting where teachers learn to do "the right thing at the right time" (Roth et al., 1999, p. 771). Furthermore, there are tacit dimensions of teaching that cannot be acquired through didactic methods but are enacted in lived experience. These aspects of teaching are not easily captured, but still they must be brought to the next generation of teachers (Roth et al., 1999). My lived experience of becoming and being a teacher shows that sensitivity is at the core of teaching. Being a sensitive, tactful teacher means having an ability to see beyond the surface and distinguish what is good and what is not good for a student (van Manen, 2015). However, it is important to emphasize, as Friesen and Osguthorpe (2018) point out, that pedagogical tact "can help us comprehend and refine the possibilities and limitations of our own abilities to speak and act" (p. 262), but it can never "assure or guarantee any one desirable or optimal outcome" (Friesen and Osguthorpe, 2018). There is always some uncertainty about how the teacher acts in every situation.

Finally, the process, of becoming and being a teacher, as described above shows how the core of teaching captured by the notion of pedagogical tact is put at risk by the influences from neoliberal policy, reducing teachers to economic tools, mediating and measuring standardized performances as efficient as possible. I would claim that teaching can never be reduced to technocratic standards or be ruled by precise descriptions. It is not a normative practice, though it has been developed in that direction and this puts the teacher into a position of constant struggle between the pedagogical alignment and the practices influenced by the increased neoliberalism.

\section{References}

de Anda, C. \& Geist- Martin, P. (2017). Memory as insight: Navigating the complexities of generational mother-daughter relationship. Qualitative Inquiry, 24(6), 403-412.

Beach, D. (2018). Structural Injustices in Swedish Education. Academic Selection and Educational Inequalities. Cham: Springer International.

Biesta, G. (2007). Why "What works" won't work: Evidence - based practice and the democratic deficit in educational research. Educational Theory, 57(1), 1-22.

Biesta, G. (2017) Education, Measurement and the Professions: Reclaiming a space for democratic professionality in education. Educational Philosophy and Theory, 49(4), 315-330.

Carlgren, I. (2009). The Swedish comprehensive school - lost in transition? Zeitschrift für Erziehungswissenschaft, 12(4), 633-649. 
Erixon Arreman, I. \& Holm, A-S. (2011). Privatisation of public education? The emergence of independent upper secondary schools in Sweden. Journal of Education Policy, 26(2), 225-243.

Evaldsson, A-C. \& Nilholm, C. (2009). Evidensbaserat skolarbete och demokrati. Pedagogisk forskning i Sverige, 14(1), 65-82.

Fišer, J. (1972). The quality of the teacher-pupil relationship - An essay on pedagogical tact. International Review of Education, 18(1), 467-472.

Friesen, N. \& Osguthorpe, R. (2018). Tact and the pedagogical triangle: The authenticity of teachers in relation. Teaching and Teacher Education, 70, 255-264.

Gibbs, P. (2014). The phenomenology of professional practice: A currere. Studies in Continuing Education, 36(2), 147-159. DOI: 10.1080/0158037X.2013.825765

Kenklies, K. (2012) Educational Theory as Topological Rhetoric: The Concepts of Pedagogy of Johann Friedrich Herbart and Friedrich Schleiermacher. Studies in Philosophy and Education, 31(3), 265-273. DOI 10.1007/s11217-012-9287-6

Klein, S.B. \& German, T. P. (2004). A theory of autobiographical memory: necessary components and disorders resulting from their loss. Social Cognition, 22(5), 460-490.

Labaree, D. F. (2000). On the nature of teaching and teacher education. Difficult practices that look easy. Journal of Teacher Education, 51(3), 228-233.

Levine, L. J. \& Pizarro, D. A. (2004). Emotion and memory research: a grumpy overview. Social cognition, 22(5), 530-554.

Levinsson, M. \& Proitz, S. T. (2017). The (Non-)Use of Configurative Reviews in Education. Education Inguiry, 8(3), 209-231.

van Manen, M. (2015). Pedagogical tact. Walnut Creek: Left Coast Press.

van Manen, M. (2014). Phenomenology of Practice. Walnut Creek: Left Coast Press.

van Manen, M. (2007). Phenomenology of Practice. Phenomenology \& Practice, 1(1), 1130 .

van Manen, M. (1997). Researching lived experience. Ontario: Althouse Press.

van Manen, M. (1991). The tact of teaching: the meaning of pedagogical thoughtfulness.

Ontario: Althouse Press.

Roth, W. (2002). Being and becoming in the classroom. Westport: Ablex Publishing. 
Roth, W-M., Masciotra, D. \& Boyd, N. (1999). Becoming-in-the-classroom: A case study of teacher development through coteaching. Teaching and Teacher Education, 15(7), 771-784.

Saevi, T. \& Foran, A. (2012). Seeing pedagogically, telling phenomenologically: Addressing the profound complexity of education. Phenomenology \& Practice, 6(2), 50-64.

Savage, G. C. (2017). Neoliberalism, education and curriculum. In B. Gobby, R. Walker, (Eds.), Powers of Curriculum, 143-165.

Westfall-Greiter, T., \& Schwarz, J. F. (2012). Planning for the unplannable: Responding to (Un)articulated calls in the classroom. Phenomenology \& Practice, 6(2), 121135. 